\title{
Linda Weidenstedt*
}

\section{Employee Empowerment and Paternalism: A Conceptual Analysis of Empowerment's Embeddedness in Communicative Contexts**}

\begin{abstract}
Empowerment as a management technique builds on the assumption that employees desire more power. Consequently, to a large extent, research on employee empowerment has focused on defining the type of power that should be contained in empowerment, identifying relevant mediating and moderating effects of and for empowerment as well as empowerment's boundary conditions such as individual and social attributes. However, less research has dealt with communicative and relational aspects and how these may impact the outcome of employee empowerment. This paper uses an interactional perspective to conceptually analyse communicative meanings entailed in employee empowerment. Building on sociological theories of communicative interaction, it is argued that focusing on leaders' and members' ascriptions of meanings to each other's communicative messages reveals paternalistic power structures that are of relevance for the failure and success of empowerment. A communicative analysis of common structural and psychological empowerment efforts suggests that members' sensemaking of their roles and situations, as defined by formal (written) and informal (psychological) contracts, may not necessarily be in line with the communicative meanings intended by leaders' actions, and vice versa.
\end{abstract}

Keywords: empowerment, paternalism, communication, leadership, management

(JEL: L0, L2, M1)

\section{Introduction}

Numerous studies on employee empowerment's positive impact on work performance, job satisfaction, innovativeness, creativity, and turnover intention support the notion of empowerment as a valuable management concept (Seibert et al., 2011; Van De Voorde et al., 2016; Zhang \& Bartol, 2010). Built on the idea of power-sharing, empowering leadership makes use of structural practices, for instance participative decision making, flat organisational structures, and work teams as well as psychologically oriented practices, for instance increasing employees' feel-

* Dr. Linda Weidenstedt: The Ratio Institute, Box 3203, SE-103 64 Stockholm, Sweden and Stockholm University, Department of Sociology, SE-106 91 Stockholm, Sweden. E-Mail: linda.weidenstedt@ratio.se.

** Date submitted: August 03, 2019.

Revised version accepted after double-blind review: March 10, 2020.

mrev, 31 (4) 2020, $444-464$ 
ing of meaningfulness, competence, self-determination, and impact (Maynard et al., 2012; Seibert et al., 2004; Spreitzer, 2008).

Despite its favourable reputation, however, empowerment comes with a set of puzzles such as the observation that empirical results of empowerments' effect on improved firm performance and effectiveness are inconclusive (Birdi et al., 2008; Staw \& Epstein, 2000; Yin et al., 2018). Also, empowerment has been seen to have rather paradoxical effects, sometimes creating disempowered and cynical rather than empowered employees (Boje \& Rosile, 2001; Ciulla, 1998; Eccles, 1993; Gvaramadze, 2008; Langfred, 2007; Wickisier, 1997).

With the discourse on employee empowerment largely being dominated by the fields of psychology and organisational behaviour, it is argued in this paper that a micro-oriented, sociological and relational point of view may contribute with a hitherto neglected perspective: The aim of this paper is to illustrate that one reason for the inconclusiveness of results on empowerment may be the communicative challenges involved in empowering leadership. The examination of the communicative understanding between leaders and members from a theoretical point of view shows that empowerment bears the risk of being experienced as paternalistic.

Resting on micro-sociological theories of interaction, as established by Mead ([1934] 1967) and Goffman (1959), the paper builds on the assumption that empowering leadership is embedded in a relational power construct that will affect the desired outcome: Empowering actions and behaviour depend on the employment context. The idea of a communicative workplace context is presented, entailing formal (working contract) and informal (psychological contract) relations. Based on the interactional and communicative perspective, it is assumed that to empower, both leader and member need to ascribe each other's formal and informal communicative messages with the appropriate expectations, meanings, and values. In a next step, the relation between common structural and psychological empowerment efforts and the communicative workplace context are analysed. It is suggested that members' sensemaking of their roles and situations, as defined by formal and informal contracts, may not necessarily be in line with the communicative meanings intended by leaders' actions, and vice versa.

The aim of this study is not to present a comprehensive analysis of all existing empowerment practices in combination with the entirety of formal and informal prerequisites. It rather uses a few of these elements to illustrate why empowerment bears the potential to be perceived as paternalistic. The paper contributes to the literature in several ways: First, a communicative context for employee empowerment is identified, which broadens the understanding of empowerment as communicatively embedded actions and behaviour. Second, the analysis of specific empowerment efforts in the context of their communicative embeddedness reveals possible differences in leaders' and members' ascriptions of meaning to these efforts. Third, relating the results of the analysis to paternalistic aspects as inherent part of empow- 
erment contributes with one explanation as to the paradoxical character of empowerment on a communicative level.

\section{Theoretical Background: The Micro-Sociological Context of Employee Empowerment}

The conceptual analysis of empowerment is based on three concepts: employee empowerment, communicative interaction and paternalism. In the following, short research overviews are given for all three concepts.

\section{Employee Empowerment}

Empowering leadership aims at creating autonomous, confident and motivated employees who experience their work as meaningful (Ahearne et al., 2005). Previous research has established that to achieve employee empowerment, different practices can be used. These can be clustered into two categories: First, so called social-structural practices, involving employees by means of structural resources that concern organisational conditions (Bowen \& Lawler, 1995; Conger \& Kanungo, 1988; Farr-Wharton et al., 2011; Kanter, 1977). A review of empowerment by Spreitzer in 2008 established, for instance, that typical social-structural empowerment practices may include (1) pay based on skills, knowledge, or competency; (2) participative decision-making (including self-managing teams); (3) flat, decentralised organisational structures; (4) an open flow of information (upwards and downwards); and (5) training (building skills and extending abilities) (Spreitzer, 2008).

Second, empowering leadership has also been shown to entail practices of a more psychological kind that aim at improving employees' self-image, feelings of motivation, and their sense of self-efficacy (Bandura, 1977; Conger, 1989; Thomas \& Velthouse, 1990). Psychological empowerment typically incorporates aspects such as summarised by Spreitzer (1995): (1) meaning; the value employees ascribe to their work in relation to their values, beliefs, ideals, behaviour, and standards; (2) competence; employees' sense of self-efficacy and belief in their ability to accomplish certain work goals; (3) self-determination; employees' feelings that they have a choice and the possibility of acting autonomously in work-related decisions, methods, etc.; and (4) impact; employees' feelings of making a difference and of having the opportunity to influence work-related outcomes in connection with, for example, strategic or administrative issues (Spreitzer, 1995, p. 1443f.; 2008, p. 57; see also Maynard et al., 2012; Seibert et al., 2011).

Empowering leadership is commonly associated with containing elements of both structural and psychological empowerment (Ahearne et al., 2005; Arnold et al., 2000; Rachael et al., 2019; Srivastava et al., 2006). Distributing social-structural empowerment resources and creating a meaningful workplace context, it is hoped to increase employees' feelings of psychological empowerment-and therewith to 
improve their performance and effectiveness (Raub \& Robert, 2010; Vecchio et al., 2010).

As mentioned previously, empowerment comes with a set of puzzles—despite its favourable reputation. For instance, research has observed that empirical results of empowerments' effect on improved firm performance and effectiveness are inconclusive (Birdi et al., 2008; Staw \& Epstein, 2000; Yin et al., 2018). Also, empowerment has been seen to have rather paradoxical effects, sometimes creating disempowered and cynical rather than empowered employees (Boje \& Rosile, 2001; Ciulla, 1998; Eccles, 1993; Gvaramadze, 2008; Langfred, 2007; Wickisier, 1997).

It could be argued that the inconclusive results are not surprising given the width of aspects that have shown to influence empowerment processes: On a macro level, research has shown that larger structures such as culture shape what employees prefer and expect their workplaces to be like. Kirkman and Shapiro's (2001) research, for instance, shows that cultural values influence employees' resistance to self-managing teams. On the organisational level, questions concerning control vs. autonomy (Collins, 1999; Rachael et al., 2019; Wall et al., 2002), role ambiguities (Cordery et al., 2010; Humborstad \& Kuvaas, 2013), and the issue of organising internal redistributions of power (Argyris, 1998; Hardy \& Leiba-O'Sullivan, 1998; Weidenstedt, 2016) become relevant. Empowerment research concerned with the micro level takes individuals' psychology into consideration, investigating boundary conditions for successful empowerment that are related to the impact of individual, personal and social attributes such as expectations, values, and attitudes (Den Hartog \& Hoogh, 2009; Maynard et al., 2012; Raub \& Robert, 2010; Srivastava et al., 2006; Vecchio et al., 2010). Labianca, Gray and Brass' (2000) study concludes, for instance, that employees' resistance to empowerment is influenced by the (mis)match of the managers' and employees' expectations concerning their roles in the empowerment process. Complementing these findings, Wong and Kuvaas (2018) examined the effect of expected vs. perceived empowerment on employees' job satisfaction and found that job satisfaction increased when perceived empowerment exceeded expected empowerment.

Due to the variety of aspects influencing the success of empowerment, researchers and practitioners alike are interested in the question of how leadership and empowerment are related and what could influence empowering processes (Maynard et al., 2012; Raub \& Robert, 2010).

\section{Communicative Interaction and The Ascription of Meaning}

From a micro-sociological perspective, empowering processes can best be described as containing a black box: What happens between the distribution of empowering resources and the emotional state of psychological empowerment is more difficult to research than the prerequisites for and the outcome of empowerment. However, how employees make sense of resources and why they do, or do not, lead to feelings 
of empowerment is a rather decisive step in empowerment processes. From an interactional perspective, what goes on in that black box could be described as the production of meaning through communication (cf. Cornelissen, 2015).

Sociological theorists of the symbolic interactionist, dramaturgical and constructivist tradition all share the idea that communicative interaction takes place within a framework, called the definition of the situation. It is constructed through the actors' actions and reactions towards each other (Berger \& Luckmann, 1966; Collins, 2004; Goffman, 1959; Mead, [1934] 1967). To be able to define a situation, actors start by taking their surroundings into consideration, in other words, the context of their interaction. Relevant aspects for the context of the situation are, for instance, geographic location, the identity of other actors, the purpose of the interaction, any kind of objects that are used during the interaction, etc. (Perinbanayagam, 1974). The concept of the definition of the situation can be traced back to, among others, sociologist Erving Goffman (1959), who introduced the idea of having and reproducing specific roles in interaction-what he referred to as impression management: Depending on the definition of the situation, actors choose an appropriate role which they have to manage accordingly. By using different means, such as objects (clothing, things) or vocabulary, actors perform their role (ibid.). Performances need to be accepted by all interactants for an interaction to run smoothly and to create a "consensual definition of the situation" (Perinbanayagam, 1974, p. 532). In less technical terms, the definition of the situation could be referred to as a social and communicative context that is created and reproduced jointly by all actors (for reasons of simplicity and stylistic flow, the term "communicative context" will be used in this paper rather than "definition of the situation", but the meaning of the two terms is identical). A prerequisite for being able to manage one's impression, i.e. one's role, is the awareness of the expectations that may exist towards that role as well as what can be expected from the other actors' role: When sharing a ride at the elevator at work, for instance, it matters significantly for the communicative context whether the other person in the elevator is the organisation's CEO, a mail carrier, or a co-worker (cf. Goffman, 1959).

Yet, the main purpose of communication is to transfer meaning. The meanings of interactions can shift depending on the communicative context and the relevant role expectations for the current interaction. Therefore, communication cannot be regarded as messages with an inherent meaning. Rather, understanding communicative interaction is highly dependent on the appropriate ascription of meanings: Actors do not receive a finished product from each other. They must add meaning to the actions of their interaction partners to make sense of them (Blumer, 1969, p. 79; cf. Mead, [1934] 1967; Carter \& Fuller, 2016). Suppose person A has knowledge about the communicative context and relevant role expectations; A must still ascribe B's message a meaning that is considered appropriate and correct in this context. 
Since the ascription of meaning to communication is the starting point for an appropriate reaction of person A to the interaction, failing to ascribe the meaning that $\mathrm{B}$ intended to convey will most likely result in misunderstandings and/or conflict (Goffman, 1967, p. 17). Accordingly, the analysis presented here will treat the ability to ascribe correct communicative meanings as the focal point of communicative interaction. In terms of empowerment, this means that leader and member must be able to ascribe each other's actions the correct, i.e. intended, meaning within the communicative context of the workplace for empowerment to succeed. ${ }^{1}$

\section{Paternalism in Communicative Interaction}

Frequently, empowerment is mentioned as diametrically opposed to paternalism: Empowerment gives power and agency, paternalism takes it away (Pellegrini \& Scandura, 2006, 2008; Tengland, 2008). At the same time, however, it has also been argued that empowerment risks being perceived as paternalistic (Eylon, 1998). How come these two concepts seem to be intertwined? Paternalism is built on an asymmetric power relation between two actors. The powerful actor A has, in the capacity of being more resourceful, power over the less powerful actor B (Dahl, 1957; Weber, [1922] 1978). Consequently, it is A and not B, who can decide whether to share some of their power with B. Also, it is up to A which kind of power is shared, how much, when, and on which terms. In other words, A dominates B. This, however, does not yet qualify as paternalism, since paternalism also involves actor A's conviction of knowing better than B what is good for B. Thus, implying a fatherly, benevolent attitude when granting B power is commonly described as paternalism (Archard, 1990; Clarke, 2002; Dworkin, 1983; Gert \& Culver, 1976; Grill, 2007; Sartorius, 1983; Sennett, 1993). While the asymmetric power relation between A and B may or may not cause general discomfort, it is rather the issue of implying that $B$ is uncapable or incompetent to know what is best for them that makes paternalism such a problematic practice: It subverts B's agency (Weidenstedt, 2016).

Employee empowerment can be argued to share one fundamental property with paternalism, namely the fact that employment relations build on asymmetric power relations between leader and member: Leaders, not members, decide whether and how to empower members. This prerequisite underlines the power imbalance and

1 In the following I use the terms "leader" and "member" to denote formal positions within a workplace hierarchy, i.e. a leader has the formal authority to lead (or manage) followers, i.e. members of an organisation, unit, or team. The choice of wording is not to disregard the importance of employees' voice and other, more balanced, power relations at the workplace, but to differentiate between those formal authorities that can implement empowerment efforts and those who cannot. It is this reasoning that motivates the narrow stipulative definition. 
makes members passive receivers of leaders' benevolence (Pellegrini \& Scandura, 2008). ${ }^{2}$

It could be argued that this power imbalance is not a given fact in all kinds of workplace and organisational contexts, since informal leaders and union representatives - to name but two examples - may contribute to a more democratic power balance and employee voice (cf. Greene et al., 2000; Pielstick, 2000; Wilkinson et al., 2018). While not intending to downplay the importance of more balanced power relations at the workplace, this conceptual analysis seeks to focus on the most asymmetric of dyadic relations: Namely those relations in which employer and employee, leader and member, have just such a clear power imbalance between them. The reason for this focus is the assumption that it is this kind of cases in which empowerment efforts are at risk of turning out as disadvantageous for the employee.

Even though research has established that empowerment practices are often welcomed by employees, the influence employees in asymmetric power relations have over which resources they receive, when, how, and why tends to be limited. As in Eylon's (1998, p. 21) powerful words: "the very fact that one group is in the position to judge if others are dis-empowered and then to decide what to 'give' so that they will become 'empowered' indicates that true empowerment is not occurring.".

Thus, while leaders might have good intentions, the meaning ascribed to their actions and words lies in the members' hands. While some may ascribe the leader intentions of support, concern, and protection, others may define the situation more in terms of authority, agency-deprivation, discrimination, and paternalism (Northouse, 1997; Pellegrini \& Scandura, 2008; Redding et al., 1994; Westwood \& Chan, 1992). In the latter case, disappointment and frustration may occur due to feeling deprived of one's agency and the right to decide what one does or does not need. This, in turn, may make a shared ascription of meaning to each other's further communicative messages difficult and result in unsatisfactory or failed empowerment.

\section{Theoretical Analysis, Step 1: The Communicative Workplace Context}

In this section, the workplace as communicative context will be analysed, followed by a section analysing empowerment as embedded in this very context. The main

2 It has been noted by previous research that industrial paternalism has evolved from an authoritarian type towards a more didactic one: While authoritarian paternalism is based on a hierarchical and commanding attitude, didactic paternalism strives for a more warm and emotional interaction, where employers seek to gain employees' approval as to the benefits of the employers' benevolent practices (cf. Ericsson, 2003; Tsutsui, 1997). In terms of empowerment, one could think of it as paternalistic in the didactic sense, seeking to establish consensus on empowerment's benefits for both employer and employee. However, the basic implication of paternalism (i.e. subverting B's agency) remains across different types of paternalism and, thus, the distinction into authoritarian and didactic paternalism will not be used in the further development of the paper's argument. 
argument in this first section is that workplace relations build on specific, communicative prerequisites, the interpretation of them, and ascription of meaning to them. These prerequisites are here identified as formal employment contracts and informal, psychological contracts— producing formal and informal relations.

\section{Contextual Meaning of Formal and Informal Contracts}

Formal, written employment contracts ordinarily include specifics about payment, work hours, holidays, and sick leave (Brown et al., 2000). They may also comprise complex details about the employee's roles and responsibilities, expectations in terms of outcome, and possibly penalties in case of misconduct or noncompliance (Poppo and Zenger, 2002; but see Fehr and Gächter, 1998, p. 848, who argue that "[t]he obligations of both employer and employee are left unspecified in many states of the world"). Since both employer and employee sign the formal employment contract, it serves as official part of their communicative workplace context.

While formal contracts are primarily treated as documented agreements about obligations that can be enforced by law (Macneil, 1985), historically, aspects entailed in contractual relationships other than those formally prosecutable have been paid less attention to (but see Durkheim in The Division of Labor in Society (Durkheim, [1893] 2014, pp. 158-180)). However, more recent research has established that such aspects often are incorporated in informal contracts, generally known as psychological contracts. Robinson and Rousseau describe psychological contracts as "[an individual's] belief that some form of a promise has been made and that the terms and conditions of the contract have been accepted by both parties" (1994, p. 246). Psychological contracts contain, first, transactional elements such as a common understanding of pay and performance. Second, they include relational elements which are more "dynamic and socioemotional rather than economic in nature" (Isaksson et al., 2010, p. 698), such as job security and loyalty. Together, formal (written) and informal (psychological) contracts combine to serve as a foundation for the employer's and employee's joint definition of the situation, i.e. the communicative workplace context.

From an interactionist point of view, the communicative context can only be assumed to fill its purpose if all actors have the communicative understanding necessary for keeping the basic functionality of the contractual foundation intact. Thus, a considerable amount of shared knowledge must exist between employer and employee to be able to ascribe the social interaction of "employment" the appropriate communicative meaning (Goffman, 1981; Mead, [1934] 1967), to identify relevant role expectations, and to enact those roles accordingly (Goffman, 1959).

A crucial communicative aspect entailed in psychological contracts is the mutual understanding of what it means to sign a formal employment contract. Both types of contracts are based on a belief in the function and meaning of employment contracts, yet the psychological contract predominates insofar as a violation of the for- 
mal employment contract could have consequences for the employee's belief in an intact psychological contract (Dabos \& Rousseau, 2004, p. 55)—while this might not apply vice versa.

\section{Contextual Meaning of Five Workplace Elements}

From a communicative micro-level point of view, it can be argued that a few elements of formal and informal contractual relations are particularly relevant for empowering leadership, since they constitute the most basic understanding of the workplace context. While certainly not exhaustive for every type of work relation, five elements were chosen to exemplify the importance of ascribing the correct meaning to each other's actions in a workplace context: (1) exchange agreement, (2) working position, (3) hierarchies, (4) responsibility for productivity, and (5) competence. The choice of these five elements is grounded in the literature: Three of them are recurrently mentioned as elements of formal and/or psychological contracts (exchange agreement, responsibility for productivity, and competence; see Isaksson et al., 2010; Poppo \& Zenger, 2002). Working position and hierarchies can, from a micro-sociological and communicative point of view, be considered decisive elements for identity formation and are thus necessary to understand the relevant roles and role expectations involved in workplace interaction (Goffman, 1959).

Element (1) concerns the exchange agreement. Employer and employee enter an exchange relationship, implying that the employer attends to the role of needing to get work done and, in exchange, compensates the employee for performing that work. In turn, the employee needs to know that he or she will be expected to fulfil the duties included in the role of being an employee (see Fehr \& Gächter, 1998). It is necessary for both parties to accept this exchange agreement of work for payment and to have shared knowledge about the possibility of negotiating conditions, such as salary or working hours, as well as how to negotiate-which includes comprehending different compensation systems.

(2) concerns the working position. Employer and employee must interpret correctly what it means to agree on a certain position for the employee within the organisation. Whether manager or assembly-line worker, the employer and employee need to know what it means to accept the assignment of a particular job position as well as which responsibilities and specific role expectations it entails.

(3) concerns hierarchies. The assignment of a specific position implies the acceptance of hierarchies in the organisation and the fact that employees most likely will have to answer to one or several leaders. This includes the shared knowledge that leaders have the right and the obligation to tell members what to do and how to do it.

(4) concerns responsibility for productivity. Employer and employee must be aware of role expectations related to responsibility and performance: They need to have 
joint knowledge about the employee's obligation to fulfil whatever work tasks accompany the working position in question. In other words, the employee is aware of the responsibility he or she has for successfully executing relevant work-related processes within a given time frame while the employer provides the employee with necessary resources.

(5) concerns competence. Employer and employee ascribe, ideally, the same meaning to the notion of competence: They agree on which competence is needed for the job at hand, that the employee in fact has that very competence-or can acquire it - and that he or she can take on responsibility for productivity and relevant work assignments.

The communicative workplace context certainly entails more elements than these. Here, they were chosen to serve as illustration for the kind of joint knowledge and correct ascription of meaning necessary for workplace relations to work. In the next step, they will also be used as illustrative foundation for the analysis of a number of empowerment practices' embeddedness in the communicative context.

\section{Theoretical Analysis, Step 2: Empowerment Practices' Embeddedness in the Communicative Workplace Context}

The main argument in this section is that empowerment cannot be self-supporting. As any other interaction, empowerment practices are embedded in a jointly created social and communicative context, meaning their success depends significantly on the meanings ascribed to them. Here, an analysis is presented in four parts, exploring the possible discrepancies in role expectations and ascriptions of meaning that could occur when leaders empower. It is also discussed which negative consequences such discrepancies can have on members' psychological empowerment and psychological contracts. Having been validated by previous research (Spreitzer, 1995, 2008), the empowerment practices mentioned earlier are used as examples (see table 1 for an overview of the analysis).

First, joint knowledge about the prerequisites and conditions of a mutual exchange agreement was discussed above as one basic element of the communicative workplace context. In terms of structural empowerment, one practice stands out as particularly relevant for the actors' ascriptions of meaning to empowerment's exchange properties: pay based on skills, knowledge, or competency. The idea of skill-based pay (SBP; also knowledge- or competency-based pay) is defined as setting "pay rates based on how many skills and competencies employees have, or jobs they potentially can do, not on the job they hold" (Giancola, 2011, p. 220).

Approaching SBP from a communicative point of view means to address the problem of whether all actors ascribe SBP the same meaning. For instance, do leaders' and members' ascriptions of meaning regarding the definition, measurement, and evaluation of relevant skills match (Hofrichter \& Spencer, 1996; Lawler, 1996, 
2000)? Since SBP aims at motivating members to learn and develop new skills and thus perform better (Lawler \& Ledford, 1986, p. 57), it also entails new roles and role expectations. For members' ascriptions of meaning to concur with those intended by the empowering leader, members must recognise that their roles and role expectations may change continuously (see Goffman, 1959). If ascriptions do not match, there is a greater risk that SBP may be experienced as unjust and disappointing by members (see Lee et al., 1999).

Since SBP encourages employees to develop more competencies to be more valuable to the company, SBP could - from a communicative point of view-be argued to foster employees' sense of meaningfulness, competence, self-determination and impact (see above on psychological empowerment practices). Being more valuable could possibly translate into increased pay, implying greater meaningfulness and impact for employees.

However, considering the communicative context in which empowerment is embedded, being encouraged to take on responsibility for developing skills can also be argued to challenge leaders' and members' expectations towards each other. The seemingly voluntary decision to acquire new skills may be ascribed a different meaning, for instance one of tacit obligation: Implied or tacit expectations as to which competencies to develop, when, and how may be interpreted as leaving little room for self-determination (see table 1). Thus, while members could ascribe SBP the meaning intended by leaders, they could also ascribe such leadership the opposite: a paternalistic, benevolent attitude that disregards individuals' own agency and wishes (Weidenstedt, 2016). Ascribing a paternalistic meaning to empowerment may result in employees' insecurity and the impression that their formal and/or informal exchange agreement is unreliable, since it is indirectly controlled by the organisation's evaluation of skill. This, in turn, could lead to the opposite of psychological empowerment: wariness, dissatisfaction, stress, and feelings of powerlessness.

Second, as previously mentioned, the communicative workplace context involves the aspects working position and hierarchies. In relation to these, structural empowerment practices intended to provide employees with autonomy regarding decisionmaking, resources, handling of information, etc. risk leading to discrepancies in ascriptions of meaning. For instance, while leaders hope to increase members' engagement, motivation, and, ultimately, performance (Markos \& Sridevi, 2010), members might ascribe the inclusion in various decision-making processes a different meaning: As in the case of SBP, greater autonomy could imply continuous direct or indirect changes regarding working position, work tasks, hierarchical structures, and areas of responsibility. 


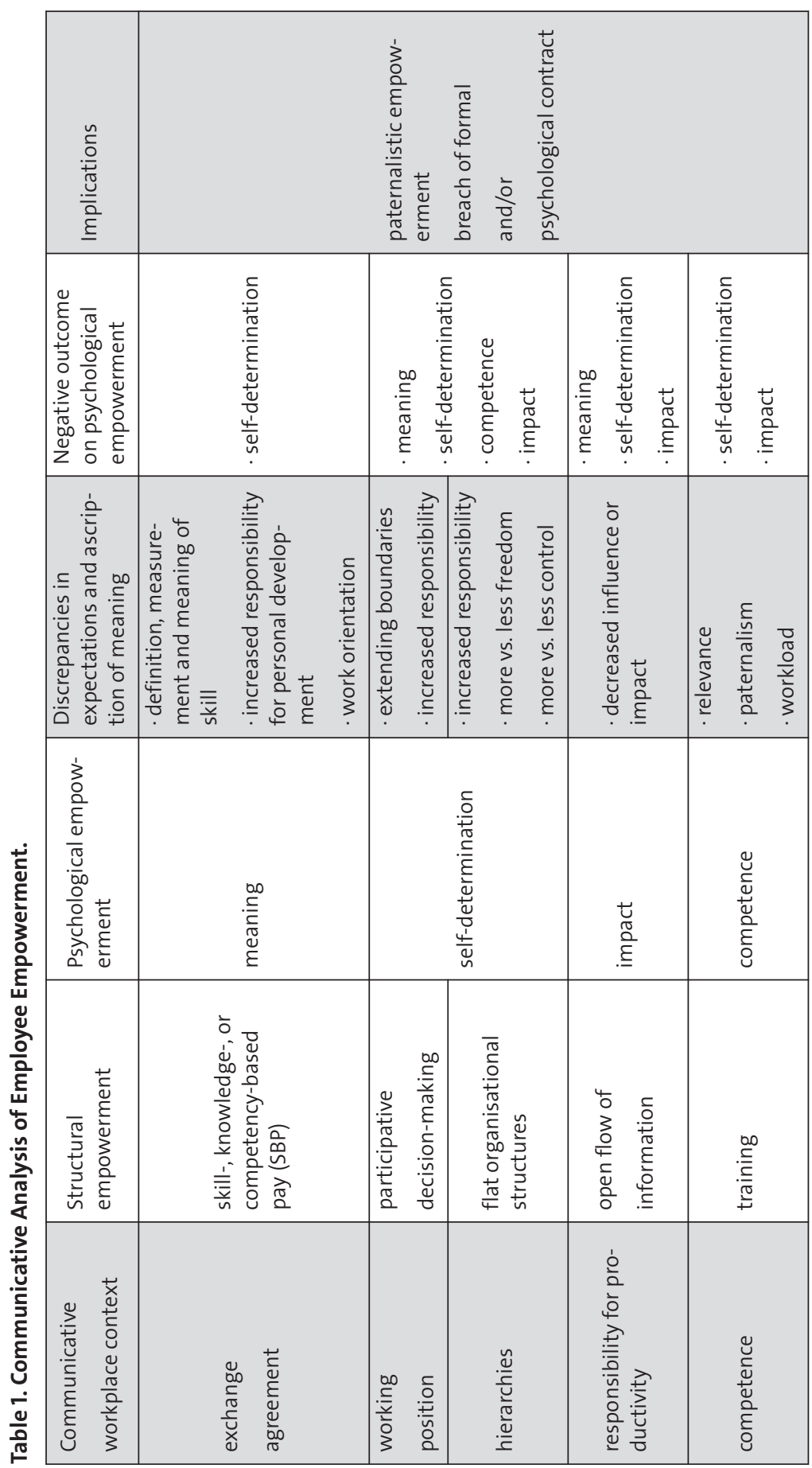


Furthermore, participative decision-making goes frequently hand in hand with flattened hierarchical structures and teamwork, encouraging members to take on more responsibility in self-managed teams (Srivastava et al., 2006). While self-managed teams imply more autonomy and less dependence on leaders, they also imply decreased individual self-determination, which is highly relevant for feelings of psychological empowerment. In self-managed teams, members do not have sole responsibility-and therefore control-over their work, since other team members have the right to intervene. Also, members can now be held responsible for the activities of other team members. This increases the responsibility of members while at the same time reducing the individual's impact on the overall outcome (on negative effects of self-managing teams, see Barker, 1993).

Thus, taking the communicative context into consideration brings several potential conflicts to light: Due to the power imbalance between leaders and members in deciding over the distribution of workplace resources, leaders decide in which areas members will be granted autonomy. Leaders may choose areas of increased responsibility and influence for members with which the latter might not necessarily feel comfortable. Failing to make sense to members, this could possibly lead to increased stress due to greater role ambiguity and role overload (Shultz et al., 2009) as well as to disruptions in terms of cooperation, coordination, and communication (Dahl, 2011). An unwanted increase in responsibility and new and extended roles could be experienced as stressful and overwhelming and lead to a diminished sense of security, self-efficacy, and self-esteem (Cast \& Burke, 2002, p. 1048ff.).

Again, while members might indeed ascribe empowerment practices the meaning intended by leaders, they might also ascribe empowering leadership a paternalistic undercurrent: the organisation assuming that all employees prefer autonomy regarding decision-making, resources, handling of information, etc., thereby not paying attention to the communicative workplace context and the formal and informal expectations that might exist between employers and employees, leaders and members.

Third, another element in the communicative workplace context is responsibility for productivity. In order to take on responsibility for one's performance, i.e. to execute one's job, members need all relevant information. The role of structural empowerment practices aimed at improving the flow of information within the organisation, both downwards (from leaders) and upwards (to leaders), is to create transparency: A downward flow includes information such as "clear goals and responsibilities, strategic direction, competitive intelligence, and financial performance in terms of costs, productivity, and quality" (Spreitzer, 2008, p. 56); the upward flow informs leaders about members' attitudes and ideas (ibid.). Spreitzer argues that the more information members get, the smarter they can work-and the better decisions they can make (ibid.). 
From a communicative point of view, two aspects are of importance: First, a downward flow of information is tightly interwoven with the idea of participative decision-making, flat organisational structures, and self-managed teams, since those organisational forms require members to be kept in the loop. Taking on responsibility requires members to ascribe meaning to their working position agreed on, their place in the organisation's hierarchy, and their role in terms of responsibility and productivity. Their interpretations also influence which meaning they ascribe to the exchange of information and whether they think that the given information enables them to make a meaningful impact and thus become psychologically empowered. Here, leaders and members may have different ideas about which kind of information is necessary, correct, adequate, etc. in order to take on responsibility, perform well and become empowered.

Second, for an upward flow of information to have a positive effect on members, a trustworthy relationship to leaders is vital. Members who take their responsibility seriously need to be reassured that conveying information on problematic issues is truly appreciated and "safe to voice" (Milliken et al., 2003, p. 1473).

As mentioned previously, the inherent power differential between leaders and members gives leaders the prerogative to decide what to communicate, how, and when. Depending on leaders' decisions, their behavior may risk communicating paternalistic attitudes towards members, knowing better than they do which information they need to fulfil their responsibility and perform well. In members, this could evoke feelings of being disrespected, reducing their agential options and hindering the execution of tasks - therewith keeping them from making an impact. Also, members might be afraid of sanctions or feel disrespected in that their opinions do not seem to matter (Schirmer et al., 2012). Ascribing meanings such as these to empowering leadership could lead to members questioning the validity of their formal and informal agreements. At worst, this might lead to an alienation of members by disempowerment on a psychological level.

Fourth, mutual understanding of the meaning of competence in the given employment relationship was previously mentioned as one of five basic elements of the communicative workplace context. Advanced vocational trainings and workshops are popular structural empowerment practices to improve members' competence and, by doing so, also their level of psychological empowerment (such as motivation, sense of self-efficacy and meaningfulness).

Studies have shown that trainings aimed at improving competence are more effective, the more the training is relevant for the trainees (Burke \& Hutchins, 2007). They have further shown that trainees who experience the training as relevant succeed better in transferring their newly acquired skills (Axtell et al., 1997). From a psychological empowerment view, members might not generally have negative attitudes towards acquiring new knowledge. Yet, they may find it difficult to make positive sense of such trainings: In cases where the type of education or training is cho- 
sen by leaders rather than members, the latter may experience the communicative messages entailed in "not getting to have a say" as paternalistic and as having their capability questioned to know themselves which competencies they do or do not have (Weidenstedt, 2016). In the eyes of members, leaders may seem to communicate that they know better how to empower and motivate members than they know themselves (Archard, 1990; Dworkin, 1983; Sartorius, 1983). Members may thus experience a lack of self-determination and trust in their competencies-counteracting a feeling of psychological empowerment. To avoid unfavourable communicative discrepancies and to ensure "clear communication between supervisors and employees about the benefits derived through training" (Guthrie \& Schwoerer, 1994, p. 416), members could be included in the choice of trainings.

\section{Discussion}

This study aimed at providing a conceptual analysis of the communicative challenges involved in empowering leadership by using an interactional and communicative perspective on the relationship between leaders and members. It was proposed that the lowest common denominator of this relationship consists of a communicative workplace context that can be regarded as the foundation on which empowering leadership rests. For empowering practices to be fruitful, leaders' and members' ascriptions of communicative meanings to empowering actions need to be agreed on.

The theoretical analysis shows that empowering leadership entails two main challenges from a communicative point of view. First, empowerment bears the risk of being experienced as paternalistic. Members might not assign the intended positive meaning to the leaders' communicative messages. Discrepancies in ascriptions of meaning can lead to negative consequences for the relationship between leaders and members, especially if members experience these differences as paternalistic and/or as violating their psychological contract (Morrison \& Robinson, 1997; Robinson, 1996; Turnley \& Feldman, 2000). Second, such perceived contractual breaches can be experienced as psychologically disempowering: Members might feel distressed and disrespected in their roles as relevant and active members of the workplace context.

There are several implications for the practice of and research on empowering leadership. First, it indicates that leaders may benefit from reflecting on the importance of ascriptions of meaning and whether their intended communicative messages could be ascribed different meanings by members. Second, the study shows that particularly one communicative meaning entailed in empowerment may cause problems for the leader-member relationship: the fact that empowerment may be perceived as paternalistic leadership, meaning the leader gets to decide whom to empower, how, and when. Third, since ascriptions of meaning depend on the definition of the situation, i.e. the communicative workplace context, members in dif- 
ferent communicative workplace contexts are likely to ascribe different meanings. Thus, members will not all prefer the same type of empowerment.

Since this study is built on very general - and theoretical-assumptions regarding working conditions and employment contracts, the aim of the analysis is to serve as an illustration of possible pitfalls. As such, the insights presented here suggest future empirical research investigating differences in empowerment preferences for different groups of employees, whether in terms of hierarchy or tasks in the workplace or in terms of their private lives or socio-economic situations.

\section{Acknowledgements}

Thanks to Bryan Caplan, Gunilla Carstensen, Jens Rydgren, Christian Sandström, Charlotta Stern, Lars Udéhn and two anonymous reviewers for critical comments and constructive feedback on earlier versions of the paper. Thanks also to Catherine V. Howard for refining my writing.

\section{References}

Ahearne, M., Mathieu, J., \& Rapp, A. (2005). To empower or not to empower your sales force? An empirical examination of the influence of leadership empowerment behavior on customer satisfaction and performance. Journal of Applied Psychology, 90(5), 945-955.

Archard, D. (1990). Paternalism defined. Analysis, 50(1), 36-42.

Argyris, C. (1998). Empowerment: The emperor's new clothes. Harvard Business Review, 76(3), 98-105.

Arnold, J. A., Arad, S., Rhoades, J. A., \& Drasgow, F. (2000). The empowering leadership questionnaire: The construction and validation of a new scale for measuring leader behaviors. Journal of Organizational Behavior, 21(3), 249-269.

Axtell, C. M., Maitlis, S., \& Yearta, S. K. (1997). Predicting immediate and longer-term transfer of training. Personnel Review, 26(3), 201-213.

Bandura, A. (1977). Self-efficacy: Toward a unifying theory of behavioral change. Psychological Review, 84(2), 191-215.

Barker, J. R. (1993). Tightening the iron cage: Concertive control in self-managing teams. Administrative Science Quarterly, 38(3), 408-437.

Berger, P. L., \& Luckmann, T. (1966). The social construction of reality: A treatise in the sociology of knowledge. Garden City, NY: Doubleday.

Birdi, K., Clegg, C., Patterson, M., Robinson, A., Stride, C. B. Wall, T. D. \& Wood, S. J. (2008). The impact of human resource and operational management practices on company productivity: A longitudinal study. Personnel Psychology, 61(3), 467-501.

Blumer, H. (1969). Symbolic interactionism. Perspective and method. Berkeley, CA: University of California Press.

Boje, D. M., \& Rosile, G. A. (2001). Where's the power in empowerment? Answers from Follett and Clegg. Journal of Applied Behavioral Science, 37(1), 90-117.

Bowen, D. E., \& Lawler, E. E. (1995). Empowering service employees. Sloan Management Review, 36(4), 73-84. 
Brown, W., Deakin, S., Nash, D., \& Oxenbridge, S. (2000). The employment contract: From collective procedures to individual rights. British Journal of Industrial Relations, 28(4), 611629.

Burke, L. A., \& Hutchins, H. M. (2007). Training transfer: An integrative literature review. Human Resource Developement Review, 6(3), 263-296.

Carter, M. J., \& Fuller, C. (2016). Symbols, meaning, and action: The past, present, and future of symbolic interactionism. Current Sociology, 64(6), 1-31.

Cast, A. D., \& Burke, P. J. (2002). A theory of self-esteem. Social Forces, 80(3), 1041-1068.

Ciulla, J. B. (1998). Leadership and the problem of bogus empowerment. In J. B. Ciulla (Ed.), Ethics, the heart of leadership (pp. 63-86). Westport, CT: Praeger.

Clarke, S. (2002). A definition of paternalism. Critical Review of International Social and Political Philosophy 5(1), 81-91.

Collins, D. (1999). Born to fail? Empowerment, ambiguity and set overlap. Personnel Review, 28(3), 208-221.

Collins, R. (2004). Interaction ritual chains. Princeton: Princeton Univ. Press.

Conger, J. A. (1989). Leadership: The art of empowering others. The Academy of Management Executive, 3(1), 17-24.

Conger, J. A., \& Kanungo, R. N. (1988). The empowerment process: Integrating theory and practice. Academy of Management Review, 13(3), 471-482.

Cordery, J. L., Morrison, D., Wright, B. M., \& Wall, T. D. (2010). The impact of autonomy and task uncertainty on team performance: A longitudinal field study. Journal of Organizational Behavior, 31, 240-258.

Cornelissen, J. P., Durand, R., Fiss, P. C., Lammers, J. C., \& Vaara, E. (2015). Putting communication front and center in institutional theory and analysis. Academy of Management Review, $40(1), 10-27$.

Dabos, G. E., \& Rousseau, D. M. (2004). Mutuality and reciprocity in the psychological contracts of employees and employers. Journal of Applied Psychology, 89(1), 52-72.

Dahl, M. S. (2011). Organizational change and employee stress. Management Science, 57(2), 240-256.

Dahl, R. A. (1957). The concept of power. Behavioral Science, 2(3), 201-215.

Den Hartog, D. N., \& De Hoogh, A. (2009). Empowering behaviour and leader fairness and integrity: Studying perceptions of ethical leader behaviour from a levels-of-analysis perspective. European Journal of Work and Organizational Psychology, 18(2), 199-230.

Durkheim, E. ([1893] 2014). The division of labor in society. New York, NY: The Free Press.

Dworkin, G. (1983). Paternalism. In R. Sartorius (Ed.), Paternalism (pp. 19-34). Minneapolis: University of Minnesota Press.

Eccles, T. (1993). The deceptive allure of empowerment. Long Range Planning, 26(6), 13-21.

Ericsson, C. (2003). Football, foundry communities and the Swedish model. Soccer \& Society, $4(1), 20-40$.

Eylon, D. (1998). Understanding empowerment and resolving its paradox. Lessons from Mary Parker Follett. Journal of Management History, 4(1), 16-28. 
Farr-Wharton, R., Brunetto, Y., \& Shacklock, K. (2011). Professionals' supervisor-subordinate relationships, autonomy and commitment in Australia: A leader-member exchange theory perspective. The International Journal of Human Resource Management, 22(17), 3496-3512.

Fehr, E., \& Gächter, S. (1998). Reciprocity and economics: The economic implications of homo reciprocans. European Economic Review, 42, 845-859.

Gert, B., \& Culver, C. M. (1976). Paternalistic behavior. Philosophy and Public Affairs, 6(1), 4557.

Giancola, F. L. (2011). Skill-based pay: Fad or classic? Compensation \& Benefits Review, 43(4), $220-226$.

Goffman, E. (1959). The presentation of self in everyday life. New York: Anchor Books.

Goffman, E. (1967). Interaction ritual: Essays on face-to-face behavior. New York: Pantheon.

Goffman, E. (1981). Forms of talk. Philadelphia: University of Pennsylvania Press.

Greene, A.-M., Black, J., \& Ackers, P. (2000). The union makes us strong? A study of the dynamics of workplace union leadership at two UK manufacturing plants. British Journal of Industrial Relations, 38(1), 75-93.

Grill, K. (2007). The normative core of paternalism. Res Publica, 13, 441-458.

Guthrie, J. P., \& Schwoerer, C. E. (1994). Individual and contextual influences on self-assessed training needs. Journal of Organizational Behavior, 15, 405-422.

Gvaramadze, I. (2008). Human resource development practice: The paradox of empowerment and individualization. Human Resource Developement International, 11(5), 465-477.

Hardy, C., \& Leiba-O'Sullivan, S. (1998). The power behind empowerment: Implications for research and practice. Human Relations, 51(4), 451-483.

Hofrichter, D. A., \& Spencer, L. M. (1996). Competencies: The right foundation for effective human resources management. Compensation \& Benefits Review, 28(6), 21-26.

Humborstad, S. I. W., \& Kuvaas, B. (2013). Mutuality in leader-subordinate empowerment expectations: Its impact on role ambiguity and intrinsic motivation. The Leadership Quarterly, 24(2), 363-377.

Isaksson, K., Cuyper, N. D., Oettel, C. B., \& Witte, H. D. (2010). The role of the formal employment contract in the range and fulfilment of the psychological contract: Testing a layered model. European Journal of Work and Organizational Psychology, 19(6), 696-716.

Kanter, R. M. (1977). Men and women of the corporation. New York: Basic Books.

Kirkman, B. L., \& Shapiro, D. L. (2001). The impact of cultural values on job satisfaction and organizational commitment in self-managing work teams: The mediating role of employee resistance. Academy of Management Journal, 44, 557-569.

Labianca, G., Gray, B., \& Brass, D. J. (2000). A grounded model of organizational schema change during empowerment. Organization Science, 11(2), 235-257.

Langfred, C. W. (2007). The downside of self-management: A longitudinal study of the effects of conflict on trust, autonomy, and task interdependence in self-managing teams. Academy of Management Journal, 50(4), 885-900.

Lawler, E. E. (1996). Competencies: A poor foundation for the new pay. Compensation \& Benefits Review, 28(6), 20-26.

Lawler, E. E. (2000). Pay strategy: New thinking for the new millenium. Compensation \& Benefits Review, 32(1), 7-12. 
Lawler, E. E., \& Ledford, G. E. (1986). Skill-based pay: A concept that's catching on. Compensation \& Benefits Review, 18(4), 54-61.

Lee, C., Law, K. S., \& Bobko, P. (1999). The importance of justice perceptions on pay effectiveness: A two-year study of a skill-based pay plan. Journal of Management, 25(6), 851-873.

Macneil, I.R. (1985). Relational contract: What we do and do not know. Wisconsin Law Sociology Review, 28, 483-525.

Markos, S., \& Sridevi, M. S. (2010). Employee engagement: The key to improving performance. International Journal of Business and Management, 5(12), 89-96.

Maynard, M. T., Gilson, L. L., \& Mathieu, J. E. (2012). Empowerment-fad or fab? A multilevel review of the past two decades of research. Journal of Management, 38, 1231-1281.

Mead, G. H. ([1934] 1967). Mind, self, and society: From the standpoint of a social behaviorist. Chicago: University of Chicago Press.

Milliken, F. J., Morrison, E. W., \& Hewlin, P. F. (2003). An exploratory study of employee silence: Issues that employees don't communicate upward and why. Journal of Management Studies, 40(6), 1453-1476.

Morrison, E., \& Robinson, S. (1997). When employees feel betrayed: A model of how psychological contract violation develops. Academy of Management Review, 22(1), 226-256.

Northouse, P. G. (1997). Leadership: Theory and practice. Thousand Oaks, CA: Sage.

Pellegrini, E. K., \& Scandura, T. A. (2006). Leader-member exchange (LMX), paternalism, and delegation in the Turkish business culture: An empirical investigation. Journal of International Business Studies, 37, 264-279.

Pellegrini, E. K., \& Scandura, T. A. (2008). Paternalistic leadership: A review and agenda for future research. Journal of Management, 34(3), 566-593.

Perinbanayagam, R. S. (1974). The definition of the situation: An analysis of the ethnomethodological and dramaturgical view. The Sociological Quarterly, 15(4), 521-541.

Pielstick, D. C. (2000). Formal vs. informal leading: A comparative analysis. Journal of Leadership Studies, 7(3), 99-114.

Poppo, L., \& Zenger, T. (2002). Do formal contracts and relational governance function as substitutes or complements? Strategic Management Journal, 23, 707-725.

Rachael, L. L., Brown, D. A., \& Sutton, N. C. (2019). Control and empowerment as an organising paradox: Implications for management control systems. Accounting, Auditing \& Accountability Journal, 32(2), 483-507.

Raub, S., \& Robert, C. (2010). Differential effects of empowering leadership on in-role and extra-role employee behaviors: Exploring the role of psychological empowerment and power values. Human Relations, 63, 1743-1770.

Redding, S. G., Norman, A., \& Schlander, A. (1994). The nature of individual attachment to theory: A review of East Asian variations. In H. C. Triandis, M. D. Dunnette \& L. M. Hough (Eds.), Handbook of industrial and organizational psychology (pp. 674-688). Palo Alto, CA: Consulting Psychology Press.

Robinson, S. L. (1996). Trust and breach of the psychological contract. Administrative Science Quarterly, 41(4), 574-599.

Robinson, S. L., \& Rousseau, D. M. (1994). Violating the psychological contract: Not the exception but the norm. Journal of Organizational Behavior, 15(3), 245-259.

Sartorius, R. (1983). Paternalism. Minneapolis: University of Minnesota Press. 
Schirmer, W., Weidenstedt, L., \& Reich, W. (2012). From tolerance to respect in inter-ethnic contexts. Journal of Ethnic and Migration Studies, 38(7), 1049-1065.

Seibert, S. E., Silver, S. R., \& Randolph, W. A. (2004). Taking empowerment to the next level: A multiple-level model of empowerment, performance, and satisfaction. The Academy of Management Journal, 47(3), 332-349.

Seibert, S. E., Wang, G., \& Courtright, S. H. (2011). Antecedents and consequences of psychological and team empowerment in organizations: A meta-analytic review. Journal of Applied Psychology, 96(5), 981-1003.

Sennett, R. (1993). Authority. New York: W.W. Norton.

Shultz, K. S., Wang, M., \& Olson, D. A. (2009). Role overload and underload in relation to occupational stress and health. Stress \& Health, 26(2), 99-111.

Spreitzer, G. (1995). Psychological empowerment in the workplace: Dimensions, measurement, and validation. Academy of Management Journal, 38(5), 1442-1465.

Spreitzer, G. (2008). Taking stock: A review of more than twenty years of research on empowerment at work. In C. Cooper \& J. Barling (Eds.), The SAGE handbook of organizational behavior (Vol. 1, pp. 54-72). Thousand Oaks: Sage.

Srivastava, A., Bartol, K. M., \& Locke, E. A. (2006). Empowering leadership in management teams: Effects on knowledge sharing, efficacy, and perfomance. The Academy of Management Journal, 49(6), 1239-1251.

Staw, B. M., \& Epstein, L. D. (2000). What bandwagons bring: Effects of popular management techniques on corporate performance, reputation, and CEO pay. Administrative Science Quarterly, 45, 523-556.

Tengland, P.-A. (2008). Empowerment: A conceptual discussion. Health Care Analysis, 16, 77-96.

Thomas, K. W., \& Velthouse, B. A. (1990). Cognitive elements of empowerment: An interpretive' model of intrinsic task motivation. Academy of Management Review, 15(4), 666-681.

Tsutsui, W. M. (1997). Rethinking the paternalist paradigm in Japanese industrial management. Business and Economic History, 26(2), 561-572.

Turnley, W. H., \& Feldman, D. C. (2000). Re-examining the effects of psychological contract violations: Unmet expectations and job dissatisfaction as mediators. Journal of Organizational Behavior, 21, 25-42.

Van De Voorde, K., Veld, M., \& Veldhoven, M. V. (2016). Connecting empowerment-focused HRM and labour productivity to work engagement: The mediating role of job demands and resources. Human Resource Management Journal, 26(2), 192-210.

Vecchio, R. P., Justin, J. E., \& Pearce, C. L. (2010). Empowering leadership: An examination of mediating mechanisms within a hierarchical structure. The Leadership Quarterly, 21(3), 530542.

Wall, T. D., Cordery, J. L., \& Clegg, C. W. (2002). Empowerment, performance, and operational uncertainty: A theoretical integration. Applied Psychology: An International Review, 51(1), 146 169.

Weber, M. ([1922] 1978). Economy and society: An outline of interpretive Sociology. Berkeley: University of California Press.

Weidenstedt, L. 2016. Empowerment gone bad: Communicative consequences of power transfers. Socius, 2, 1-11. 
Westwood, R. I., \& Chan, A. (1992). Headship and leadership. In R. I. Westwood (Ed.), Organisational behaviour: Southeast Asian perspectives (pp. 118-143). Hong Kong: Longman.

Wickisier, E. L. (1997). The paradox of empowerment-A case study. Empowerment in organizations, 5(4), 213-219.

Wilkinson, A., Gollan, P. J., Kalfa, S., \& Xu, Y. (2018). Voices unheard: employee voice in the new century. International Journal of Human Resource Management, 29(5), 711-724.

Wong, S. I., \& Kuvaas, B. (2018). The empowerment expectation-perception gap: An examination of three alternative models. Human Resource Management Journal, 28(2), 272-287.

Yin, Y., Wang, Y., \& Lu, Y. (2018). Why firms adopt empowerment practices and how such practices affect firm performance? A transaction cost-exchange perspective. Human Resource Management Review, 29(1), 111-124.

Zhang, X., \& Bartol, K. M. (2010). Linking empowering leadership and employee creativity: The influence of psychological empowerment, intrinsic motivation, and creative process engagement. Academy of Management Journal, 53(1), 107-128. 